\title{
Needle Device
}

National Cancer Institute

\section{Source}

National Cancer Institute. Needle Device. NCI Thesaurus. Code C50290.

A device part with a long, slender, pointed shape. 